Jurnal Keperawatan Padjadjaran /Padjadjaran Nursing Journal

ISSN 2338-5324 (print)

ISSN 2442-7276 (online)

Online di http://jkp.fkep.unpad.ac.id

DOI : $10.24198 / \mathrm{jkp}$

\title{
Analyzing Factor that Affecting of Ventilator Associated Pneumonia
}

\author{
Yuliyana Kumaladewi, Aan Nuraeni, Sari Fatimah \\ Faculty of Nursing, Universitas Padjadjaran \\ Email :yuliyanakumaladewi@gmail.com
}

Submitted: 8-7-2017 Accepted: 30-4-2018 Published: 30-4-2018

\begin{abstract}
Background: Ventilator associated pneumonia (VAP) has been known to be the most common nosocomial infection in Intensive Care Unit (ICU). VAP increases length of care, cost, morbidity and mortality of patients in ICU. The ICU of RSMH Palembang have already been doing prevention of VAP incidence through VAP bundles, but the number of incidence were still high. Purpose: This study aimed to identify the factors associated with VAP incidence among the patients in ICU RSMH Palembang. Method: this study was quantitative study with kohort prospective approach. Samples were recruited from ICU RSMH Palembang using consecutive sampling technique for 4 months period $(n=61)$. Data were collected using a questionnaire package consisting of a demographic questionnaire, CPIS instrument, APACHE II, an observation sheets that measure duration of using antibiotics, duration of using ventilator, reintubation and hand hygiene compliance. Data were analyzed using descriptive quantitative and logistic regression analysis. Results: VAP occured in 12 patients (19.7\%). Bivariate test result with $\alpha: 5 \%$ have shown that APACHE II (p:0.043), duration of using antibiotic (p:0.023), duration of using ventilator $(\mathrm{p}: 0.001)$ and reintubation $\mathrm{p}:(0.001)$ were related to the incidence of VAP. Logistic regression analysis shows that reintubation $(\mathrm{OR}=0.035 ; \mathrm{CI} 95 \%: 0.28-0.658 ; \mathrm{p}=0.013)$ and duration of ventilator $>5$ days $(\mathrm{OR}=0.082$; CI 95\%: 0.09-0.74; $\mathrm{p}=0.026)$ were significant factor that affecting VAP. Conclusion. Reintubation was the most related factor with VAP incidence. It is recommended for doctors and nurses to conduct a proper and thorough assessment before extubation to minimalize the risk of reintubation.
\end{abstract}

Keywords: ICU, Risk factor, Ventilator Associated Pneumonia, VAP. 
Yuliyana Kumaladewi : Analyzing Factor that Affecting of Ventilator Associated Pneumonia

\section{Introduction}

Ventilator associated pneumonia (VAP) is the most common nosocomial infection amongs adult patients in critical area with prevalence incidence between 15-45\%. VAP give a bad impact for patients, family, even healthcare institution (hospital) because VAP could prolongs duration of ventilator and prolongs hospital stay until 7-9 days with mortality rate over $50 \%$. Each of patient with VAP drives up hospital cost between \$10.019-\$13.647 for diagnostic and medicine (Galal, 2016; Jaimes, La, Go, Mu, \& Ram1, 2007; Klompas et al., 2014; Teo, 2012; Wiryana, 2007).

VAP incidence were affected by many factor. According to Persatuan Dokter Paru Indonesia or PDPI (2003), risk factors of VAP consist of endogen factor (host) and exogen factor which interact each other to make colonization of pathogen micro-organism on upper respiration tract or gastrointestinal. Some of research found that the most significant factor were from host, especially high of APACHE II score on ICU admission (Brotfain et al., 2016; Karatas, Saylan, \& Kostakogl, 2016; Tseng et al., 2012).

Centres For Disease Control or CDC (2003) explains some condition that can causes VAP beside host factor; increases of colonization in orofaring and gastrointestinal tract; aspiration that invaded lower respiration tract and condition that could prolong duration of ventilator. Antibiotic therapy was one of condition which could increase colonization on orofaring (PDPI, 2003). Some of study said that long course of antibiotic is one of significant factor that could lead to VAP (Karatas, Saylan, \& Kostakogl, 2016; Lahoorpour, Delpisheh, \& Afkhamzadeh, 2013).

Conditions that can cause an aspiration are supine potition, nasogastric tube, reintubation, immobillization due to trauma, surgery procedure on head, thoracic, neck and abdominal (CDC, 2003). Patients with prolong duration of ventilator could experience VAP because of high risk to get contamination from medical staff hands. The study found that adding one day of mechanical ventilation can increases microorganism pathogen until $13-55 \%$. That is why, the duration of ventilator $>5$ duration is a significant factor that related to VAP incidence (Sheng et al., 2014).

Contamination from medical staff hands was one of the factor that can prolong duration of ventilator (CDC, 2003). Study of 352 patient that use mechanical ventilation in India found that patients who got controling and preventing infection intervention and treat with alcohol-based handrub have low incidence of VAP better than patients who didn't get intervention (Saramma, Krishnakumar, Dash, \& Sarma, 2011). From the conditions that can caused an aspiration and VAP, a number of studies have shown that reintubation were the most common and significant factor that affecting on VAP (Joseph, Sistla, Dutta, Badhe, \& Parija, 2009; Karatas, Saylan, \& Kostakogl, 2016; Sheng et al., 2014).

The average prevalence of VAP on RSMH Palembang were $6.55 \%$ in 2015 . This incidence exceed the indicator number for quality standard from minister of health (2016) which is $<5.8 \%$. On January-July 2016, the average prevalence of VAP in GICU $\mathrm{RSMH}$ were $4.25 \%$ and this was the highest incidence of nosocomial in RSMH. This VAP incidence were pretty high than others vertical hospital that have the same level which is RSHS Bandung with prevalence were $2.76 \%$ on 2016 .

A number of efforts had already done to decrease VAP incidence including applying VAP bundles based on CDC. VAP incidence which were still high eventhough prevention program already done, was one of the reason to conduct a research in GICU RSMH. Previous research have shown that the most significant and common factor of VAP consist of APACHE II score, duration of antibiotic theraphy, duration of ventilator, reintubation and hand hygiene compliance. These factors were coming from international research which has many differences with Indonesian characteristics such as patient condition and physician skills when performing ventilatorrelated actions including intubation. So that, further research is needed as a basis to improve management and reduction of VAP in Indonesia. 
Yuliyana Kumaladewi : Analyzing Factor that Affecting of Ventilator Associated Pneumonia

\section{Method}

This study was an observational analytic study using a prospective cohort design. Population of this study were all GICU patients who used ventilator in RSMH Palembang amounted to an average of 40 people per month. A total of 61 patients were taken as a sample using consecutive sampling with inclusion criteria of patients who used ventilators $>48$ hours without pneumonia at ICU admission and have aged $>17$ years.

This research conducted in GICU RSMH. Variables that measured in this study consist of dependent variable which is VAP and independent variables which are APACHE II score, duration of antibiotic, duration of ventilator, re-intubation and hand hygiene compliance. Instruments in this study consist of CPIS instruments, APACHE II instruments, WHO hand hygiene compliance audit form, and VAP daily surveillance forms. CPIS is a valid instrument in enforcing VAP diagnosis (Cass, Mckeown, Kelly, \& Member, 2011). The assessment consist of clinical signs of pneumonia, radiology, laboratory and results of micro-organism culture, which consistent with CDC criteria for Pneumonia 1 and 2 (CDC, 2014). Research process begin with preparation by doing inform consent to patient's family. If they are willing to participate, we calculated APACHE II score on first 24 hours of admission and CPIS score was counted on the first and second duration of hospitalization, patient that have CPIS score $>6$ was selected as a sample. Sample were monitored at day 3 , day 4 and every 3 days until patient leaves ICU or dies. Duration of antibiotics, duration of ventilator and re-intubation were monitored from admission until patient leaves or die in ICU. Observation of hand hygiene compliance was conduct every 30 minutes by assistant who got trained by researcher. Data analysis in this study consisted of univariate analysis, bivariate analysis with chi square, and multivariate analysis with regression logistic.

Table 1 Patient Charactheristic $(\mathrm{N}=61)$

\begin{tabular}{|c|c|c|c|}
\hline & Charactheristic & f & $\%$ \\
\hline \multirow[t]{2}{*}{ Gender } & Male & 37 & 60.7 \\
\hline & Female & 24 & 39.3 \\
\hline \multirow[t]{6}{*}{ Age } & Teenager $=17-25$ years old & 11 & 18 \\
\hline & Early Adults $=26-35$ years old & 7 & 11.5 \\
\hline & Late Adults $=36-45$ years old & 17 & 27.9 \\
\hline & Early Elder $=46-55$ years old & 10 & 16.4 \\
\hline & Late Elder $=56-65$ years old & 8 & 13.1 \\
\hline & Geriatrics $=>65$ years old & 8 & 13.1 \\
\hline \multirow[t]{6}{*}{ Conscious Level } & Compos Mentis (14-15) & 0 & 0 \\
\hline & Apatis ( 12-13) & 2 & 3.3 \\
\hline & Delirium ( 11-10) & 24 & 39.3 \\
\hline & Somnolen (9-7) & 14 & 23 \\
\hline & Stupor (6-4) & 13 & 21.3 \\
\hline & Coma $(<3)$ & 8 & 13.1 \\
\hline \multirow[t]{6}{*}{ Cause of Admission } & Surgery & 50 & 82 \\
\hline & - Emergency & 28 & 56 \\
\hline & - Elective & 22 & 44 \\
\hline & Medical Disease & 11 & 18 \\
\hline & - Emergency & 7 & 63.6 \\
\hline & - Other Units & 4 & 36.3 \\
\hline
\end{tabular}


Yuliyana Kumaladewi : Analyzing Factor that Affecting of Ventilator Associated Pneumonia

\begin{tabular}{|c|c|c|c|}
\hline \multirow[t]{6}{*}{ VAP } & Yes & 12 & 19.7 \\
\hline & - Death & 5 & 41.7 \\
\hline & - Life & 7 & 58.3 \\
\hline & No & 49 & 80.3 \\
\hline & - Death & 10 & 20.4 \\
\hline & - Transfer to Other Unit & 39 & 79.5 \\
\hline \multirow[t]{2}{*}{ APACHE II Score } & $\operatorname{High}(>20)$ & 23 & 37.7 \\
\hline & Low $(<20)$ & 28 & 62.3 \\
\hline \multirow[t]{2}{*}{ Duration of Antibiotics } & Long-course antibiotics & 15 & 24.6 \\
\hline & Short-course antibiotics & 46 & 75.4 \\
\hline \multirow[t]{5}{*}{ Reintubation } & Yes & 19 & 31.1 \\
\hline & - Autoextubation & 3 & 15.7 \\
\hline & - Fail of extubation & 11 & 57.8 \\
\hline & - Migration/clotting & 4 & 21.0 \\
\hline & No & 42 & 68.9 \\
\hline \multirow[t]{2}{*}{ Duration of Ventilator } & $>5$ duration & 29 & 47.5 \\
\hline & $<5$ duration & 32 & 53.5 \\
\hline \multirow{2}{*}{$\begin{array}{l}\text { Hand Hygiene } \\
\text { Compliance (Mean: 84,7) }\end{array}$} & Yes & 33 & 54.1 \\
\hline & No & 28 & 45.9 \\
\hline \multirow[t]{4}{*}{ Causative Organism } & Acinetobacter calcoaceticus & 6 & 54.54 \\
\hline & Klebsiella Pneumonia & 2 & 18.18 \\
\hline & Stapyloccoccus Aureus & 2 & 18.18 \\
\hline & Escherichia Coli & 1 & 9.09 \\
\hline \multirow[t]{3}{*}{ Criteria of VAP } & Pneumonia 1 & 11 & 91.67 \\
\hline & Pneumonia 2 & 1 & 8.3 \\
\hline & Pneumonia 3 & 0 & 0 \\
\hline \multirow[t]{2}{*}{ Type of VAP } & Late Onset & 11 & 91.67 \\
\hline & Early Onset & 1 & 8.3 \\
\hline
\end{tabular}

\section{Univariate Analysis}

Table 2 Bivariate Analysis Of Risk Factors For VAP

\begin{tabular}{ll}
\hline \multicolumn{1}{c}{ Variable } & p Value \\
\hline APACHE II Score & $0.043^{*}$ \\
Duration of Antibiotics & $0.023^{*}$ \\
Duration of Ventilator & $0.001^{*}$ \\
Reintubation & $0.001^{*}$ \\
Hand Hygiene Compliance & $0.751^{*}$ \\
\hline "chi square &
\end{tabular}


Yuliyana Kumaladewi : Analyzing Factor that Affecting of Ventilator Associated Pneumonia

\section{Bivariate Analysis}

We found that APACHE II score, duration of antibiotic theraphy, duration of ventilator and reintubation were associated with VAP in GICU RSMH Palembang, after analysis with alpha level 5\%.

\section{Multivariate Analysis}

After regression logictic analysis, we found that reintubation and duration of ventilator were the most significant factor that associated with VAP (have the highest OR number) where as reintubation was the most affecting factor. The probability of VAP occurring in patients with re-intubation and duration of use of the ventilator $>5$ days was $92.2 \%$, for patients experiencing re-intubation with

Table 3 Multivariate logistic regression analysis of risk factors for VAP

\begin{tabular}{|c|c|c|c|c|c|}
\hline Variable & B & SE & Wald & $\begin{array}{c}\text { OR } \\
(95 \% \mathrm{CI})\end{array}$ & p Value \\
\hline \multicolumn{6}{|l|}{ Duration of Ventilator } \\
\hline$->5$ duration & -2.502 & 1.123 & 4.965 & 0.082 & $0.26^{*}$ \\
\hline$-<5$ duration & & & & $(0.09-0.74)$ & \\
\hline \multicolumn{6}{|l|}{ Reintubation } \\
\hline - Yes & -2.003 & 0.808 & 6.139 & 0.135 & $0.013^{*}$ \\
\hline - No & & & & $(0.28-0.658)$ & \\
\hline Constanta & 4.086 & 1.121 & 13.288 & 1 & 0.000 \\
\hline
\end{tabular}

ventilator duration $<5$ days was $15.39 \%$ and patients not reintubating but using ventilator $>5$ days was $13.8 \%$.

\section{Discussion}

In this study, APACHE II score that influences VAP could be caused by the characteristics of respondents who have GCS $<10$, elder age and history of emergency surgery. Respondents with low consciousness was tend to lost their cough and swallowing reflexes, this may increase the risk of aspiration that causes VAP (Augustyn, 2007). According to CDC (2003) elderly patients tend to have a high gastric $\mathrm{pH}$ or $>4$. This condition causes microorganism to multiply more easily and aspirate to lower respiratory tract causing VAP. Sheng (2014) have stated that emergency operations affecting VAP because most of emergency operations were experienced by trauma patients that likely to be exposed to larger infections due to open port de entry. In this research, $28 \%$ patient admission on ICU caused by emergency surgery have a higher risk to get VAP.

The results of statistical tests show that duration of antibiotics affecting on
VAP incidence. The results of this study are consistent with a meta-analysis of six randomized control trials which states that using antibiotic over a 10-day or long course may increase the incidence of VAP than 7-8 days. Using antibiotic for 7-8 days significantly reduced the incidence of VAP and preventing multi-resistant antibiotic bacteria from spreading and becoming emerging disease (Pugh, Grant, Rpd, \& Dempsey, 2015).

The statistical test results show that hand hygiene compliance didn't influenced VAP incidence. The results of this study differ from random control trial by Trick (2003) which stated that used of ring and lack of hand hygiene compliance is associated with increased incidence of VAP. A total of $45.9 \%$ of respondents were treated by disobedient staff and the average hand hygiene compliance was $84.7 \%$. Interventions which were observed in this study were only ventilator-related measures such as nebulizer, suction, oral hiegene, circuit replacement, ETT plaster replacement, tracheostomy care, intubation and sputum culture retrieval. However, because of the observation is only 30 minutes based on KEMENKES guidance of surveillance, there are some actions above 
Yuliyana Kumaladewi : Analyzing Factor that Affecting of Ventilator Associated Pneumonia

were not documented and can not represent compliance for 24 hours. Therefore, the next researcher were suggested to make an observation in a longer time.

Statistical result shows duration of ventilator $>5$ days influenced VAP incidence. This results consistent with retrospective study from Sheng et al. (2014) who stated duration of ventilator $>5$ days affecting VAP incidence because of bacteria colonization that increased $13-55 \%$ each day every additional of ventilator days. The research was looking at the oral health status of patients with ventilators found that gram-negative bacteria increased $50 \%$ on fourth day and seventh day of where as the number of bacteria in oral more than in the tracheal (Munro et al., 2006). Another study comparing clorhexidine and povidon iodine also suggested that there was a decrease in the amount of bacteria colonization to $82 \%$ after oral hygiene (Widani et al., 2015). Therefore, it is important for nurses performed oral hiegene appropriately to decrease duration of ventilator and prevent VAP.

The statistical test shown that reintubation affecting on VAP incidence. Based on nosocomial infection concept by Depkes (2009), infection chain consist of hosts, agents (microorganisms) and environments that influenced each other. Hosts that are vulnerable (in this case that have a high APACHE II) may be exposed to VAP due to the presence of an agent (microorganism causation) brought in by transmission from medical staff, environmental or hand contact. Re-intubation process injures epithelial tissue or mucous membranes becoming a port de entry for microorganism. These results also consistent with study that stated environment and hosts interact each other to make an infection, therefore it's important to maintain environmental conditions (Sunartyasih \& Kartikasari, 2013). This result also consistent with Karatas et al. (2016) who stated that patient with re-intubation have a risk to get VAP9-fold higher with $p$ value $<0.001$ because of aspiration from oropharyngeal bacteria that have been contaminated with flora colonization into the pulmonary parenchyma. Re-intubation could be prevented by using Non Invasive Ventilator (NIV), preventing the ETT from sudden removal and planning extubation according to the weaning protocol (Coppadoro, Bittner, \& Berra, 2012; Sheng et al., 2014). The incidences of re-intubation in GICU RSMH mostly caused by extubation failure. Therefore, it is important to give a training about extubation preparedness assessment for nurses and doctors in ICU.

\section{Conclusion}

Risk factors that affecting VAP incidence in GICU RSMH Palembang are APACHE II score, duration of antibiotic, duration of ventilator and re-intubation. From the four factors above, the most influential factor on VAP were the duration of ventilator and reintubation.

Nurses should pay more attention to patients with high risk of VAP including patients with high APACHE II scores $(>20)$, duration of antibiotics $>8$ days, reintubation, ventilator duration $>5$ days. Critical nurses must also calculate APACHE II in the first 24 hours of admission, perform proper oral hygiene, exercise strict antibiotic surveillance, conduct an extubation readiness assessment for preventing VAP. The hospital should make a policy about using antibiotics $<8$ days, making policy and training related to proper hygiene oral protocols, making policy and training related to extubation decision making and extubation techniques for clinicians and critical nurses.

\section{References}

Augustyn, B. (2007). Ventilator-associated pneumonia: Risk factor and prevention. Critical Nurse, 27(4), 32-39. https://doi. org/10.1016/S0924-8579(98)00037-5.

Brotfain, E., Borer, A., Koyfman, L., SaidelOdes, L., Frenkel, A., Gruenbaum, S.E., ..., Klein, M. (2016). Multidrug resistance acinetobacter bacteremia secondary to ventilator-associated pneumonia: Risk factors and outcome. Journal of Intensive Care Medicine, 1-7. https://doi. org/10.1177/0885066616632193.

Cass, A.L., Mckeown, R.E., Kelly, J.W., 
Yuliyana Kumaladewi : Analyzing Factor that Affecting of Ventilator Associated Pneumonia

\& Member, C. (2011). Hospital infection control practice: Preventing, identifying and measuring healthcare associated infections in an ever-changing environment. University of South Carolina.

CDC. (2003). Guideline for preventing health care associated pneumonia. Atlanta.

CDC. (2014). Ventilator-Associated Pneumonia (VAP) event. Centers for Disease Control and Preven Device Assoc Incidence, 6(1), 6-14. http://www.cdc.gov/nhsn/pdfs/ pscmanual/6pscvapcurrent.pdf. Accessed August , 2014., (January), 1-14.

Coppadoro, A., Bittner, E., \& Berra, L. (2012). Novel preventive strategies for ventilator-associated pneumonia. Critical Care, 16(2), 210.

Depkes. (2009). Pedoman pencegahan dan pengendalian infeksi di RS dan fasilitas pelayanan kesehatan lainnya. Jakarta.

Galal, Y.S. (2016). Ventilator-Associated Pneumonia: Incidence, risk factors and outcome in Paediatric Intensive Care Units at Cairo University Hospital. Journal of Clinical and Diagnostic Research, 10 (September 2014). https://doi.org/10.7860/ JCDR/2016/18570.7920.

Jaimes, F., La, G. De, Go, E., Mu, P., \& Rami, J. (2007). Incidence and risk factors for ventilator-associated pneumonia in a developing country: Where is the difference ?. pp 762-767. https://doi.org/10.1016/j. rmed.2006.08.008.

Joseph, N.M., Sistla, S., Dutta, T.K., Badhe, A.S., \& Parija, S.C. (2009). Ventilatorassociated pneumonia in a tertiary care hospital in India: incidence and risk factors. $J$ Infect Dev Ctries, 3(10), 771-777.

Karatas, M., Saylan, S., Kostakogl, G.Y. (2016). An assessment of ventilatorassociated pneumonias and risk factors identified in the Intensive Care Unit. Pak $J$ Med Sci, 32(4). https://doi.org/doi: http:// dx.doi.org/10.12669/pjms.324.10381.
Kemenkes. (2016). Pedoman teknis penilaian indikator kinerja individu (IKI) Direktur Utama RS Umum/Khusus dan Kepala Balai di Lingkungan Dirjen Pelayanan Kesehatan RI (2016). Indonesia.

Klompas, M., Branson, R., Eichenwald, E.C., Greene, L.R., Howell, M.D., Lee, G., ..., Berenholtz, S.M. (2014). Strategies to prevent ventilator-associated pneumonia in acute care hospitals: 2014 Update. Infection Control \& Hospital Epidemiology, 35(8), 915-936. https://doi.org/10.1086/677144.

Lahoorpour, F., Delpisheh, A., \& Afkhamzadeh, A. (2013). Risk factors for acquisition of ventilator-associated pneumonia in adult intensive care units. Pakistan Journal of Medical Sciences, 29(5), 1105-1107. https://doi.org/10.12669/ pjms.295.3375.

Munro, C.L., Grap, M.J., Jr, E., Mckinney, J., Sessler, C., \& Hummel III, R. S. (2006). Oral health status and development of ventilatorassociated pneumonia: A descriptive study. American Journal of Critical Care, 15(September), 157-174. https://doi. org/10.1149/2.0121510jss.

PDPI. (2003). Pneumonia nosokomial. pedoman diagnosis \& penatalaksanaan pneumonia nosokomial di Indonesia. Perhimpunan Dokter Paru Indonesia, Jakarta.

Pugh, R., Grant, C., Rpd, C., \& Dempsey, G. (2015). Short-course versus prolonged-course antibiotic therapy for hospital-acquired pneumonia in critically ill adults ( Review ). Cochrane Library, (8), 1-43. https://doi. org/10.1002/14651858.CD007577.pub3. www.cochranelibrary.com.

Saramma, P.P., Krishnakumar, K., Dash, P.K., \& Sarma, P.S. (2011). Alcoholbased hand rub and ventilator-associated pneumonia after elective neurosurgery: An interventional study. Indian Journal of Critical Care Medicine: Peer-Reviewed, Official Publication of Indian Society of Critical Care Medicine, 15(4), 203-208. https://doi. org/10.4103/0972-5229.92069. 
Yuliyana Kumaladewi : Analyzing Factor that Affecting of Ventilator Associated Pneumonia

Sheng, W., Xing, Q., Hou, W., Sun, L., Niu, Z., Lin, M., \& Chi, Y. (2014). Independent risk factors for ventilator-associated pneumonia after cardiac surgery. Journal of Investigative Surgery, 27(5), 256-261. https://doi.org/10.3 109/08941939.2014.892652.

Sunartyasih, R., \& Kartikasari, L.A. (2013). Hubungan host dan lingkungan dengan manifestasi klinis hepatitis (A The Relationships between Host and Environtment with Clinical Manifestation of Hepatitis). Jurnal Keperawatan Padjadjaran, 1(2), 72-78.

Teo, H.K. (2012). VAP prevention barriers and facilitattors of provider guideline adherence. Universit of California, San Fransisco.

Trick, W. E., Vernon, M. O., Hayes, R. A., Nathan, C., Rice, T. W., Peterson, B. J., .. Weinstein, R. A. (2003). Impact of ring wearing on hand contamination and comparison of hand hygiene agents in a hospital. Clinical Infectious Diseases, 36(11),
1383-1390.

Tseng, C.-C., Huang, K.-T., Chen, Y.C., Wang, C.-C., Liu, S.-F., Tu, M.-L., ..., Lin, M.-C. (2012). Factors predicting ventilator dependence in patients with ventilator-associated pneumonia. The Scientific World Journal, 547241. https://doi. org/10.1100/2012/547241.

Widani, N.L., Nasution, Y., Tinggi, S., Kesehatan, I., Jakarta, S.C., \& Masyarakat, F.K. (2015). Perbandingan oral care menggunakan povidone iodine $1 \%$ dengan chlorhexidine $0,2 \%$ terhadap jumlah bakteri di mulut pada pasien penurunan kesadaran. (The comparison of oral care using povidoneiodine $1 \%$ and chlorhexidine $0.2 \%$ to the amount of bacteria). Jurnal Keperawatan Padjadjaran, 3(3), 185-192.

Wiryana, M. (2007). Ventilator-associated pneumonia. Jurnal Penyakit Dalam, 8(3), 254-268. https://doi.org/10.1093/bjaed/ mkv046. 